\title{
Afyon ve Kütahya Volkanitlerinin Betonda Mineral Katkı Olarak Kullanımı
}

\section{Utilization of Afyon and Kütahya Volcanites as Mineral Additive in Concrete}

\author{
Cenk Karakurt $^{1 *}$, Yaşar Kibici ${ }^{2}$, Mehmet Uğur Toprak ${ }^{3}$,Oğuzhan Ateş ${ }^{4}$ \\ Geliş / Received: 19/12/2020 \\ Revize / Revised: 31/01/2021 \\ Kabul / Accepted: 02/02/2021
}

ÖZ

Artan nüfusun tetiklediği sanayi ve barınma ihtiyaçlarının temelini oluşturan inşaat sektörü yoğun malzeme tüketiminin olduğu bir pazardır. İnşaat sektöründe yaygın şekilde kullanılan beton farklı malzemelerin bir araya gelmesiyle elde edilen kompozit bir yapı malzemesidir. Betonun temel ve en pahalı bileşeni olan çimento tüketiminin beton tasarımında azaltılması hem ekonomik hem de çevresel kazanımlar sağlamaktadır. Bu çalışmada Afyon ve Kütahya yöresinde bol miktarda bulunan volkanitlerin (tüf, pomza) ile dolomitik kireçtaşlarının alterasyonundan oluşan Terra Rosaların beton üretiminde doğal katkı malzemesi olarak kullanılabilirliği araştırılmıştır. Beton karışımında çimento yerine $\% 10, \% 20$ ve \%30 oranlarında kullanılan bu malzemelerin işlenebilirlik ve dayanım performansı referans karışım ile karşılaşıırılarak değerlendirilmiştir. Pomza kullanılan betonlarda işlenebilirlik \%15 azalmış Tüf kullanılan betonlarda Basınç dayanımları \% 40 'a kadar düşmüştür. Elde edilen sonuçlardan özellikle ileri yaşlarda dayanım performansının olumlu yönde etkilendiği görülmüştür.

Anahtar Kelimeler- Tüf, Terra Rosa, Pomza, Beton, Dayanım

\begin{abstract}
The construction sector, which forms the basis of the industrial and housing needs triggered by the increasing population, is a market with intense material consumption. Widely used in the construction industry, concrete is a composite building material obtained by combining different materials. The reduction of cement consumption, which is the basic and most expensive component of concrete, in concrete design, provides both economic and environmental benefits. In this study, the usability of volcanites (Tuff, Pumice) and weathering product of limestone/dolomitic limestone (Terra Rossa) which are abundant in Afyon and Kütahya regions, as natural mineral additives in concrete production was investigated. The workability and strength performance of these materials, which are used at the ratios of $10 \%, 20 \%$ and $30 \%$ instead of cement in the concrete mixture, have been compared with the reference mixture. Workability in concretes using pumice has decreased by $15 \%$; compressive strength has decreased up to $40 \%$ in concretes using tuff. It was seen from the results that the strength performance was positively affected, especially in older ages.
\end{abstract}

\section{Keywords- Tuff, Terra Rossa, Pumice, Concrete, Strength}

1*Sorumlu yazar iletişim: cenk.karakurt@bilecik.edu.tr (https://orcid.org/0000-0002-4204-5341) İnșaat Mühendisliği Bölümü, Bilecik Șeyh Edebali Üniversitesi, Mühendislik Fakültesi, Bilecik, Türkiye 2İletişim: yasar.kibici@bilecik.edu.tr (https://orcid.org/0000-0002-6331-8521) İşaat Teknolojisi Programı, Bilecik Şeyh Edebali Üniversitesi, Meslek Yüksek Okulu, Bilecik, Türkiye 3iletişim: mugur.toprak@ dpu.edu.tr (https://orcid.org/0000-0001-5483-2871) Inşaat Mühendisliği Bölümü, Kütahya Dumlupınar Üniversitesi, Mühendislik Fakültesi, Kütahya, Türkiye 4İletișim: 6198998@ogrenci.bilecik.edu.tr (https://orcid.org/0000-0001-5729-5872)

Inş̧aat Mühendisliği Anabilim Dalı, Bilecik Şeyh Edebali Üniversitesi, Bilecik, Türkiye 


\section{GíRiş}

Dünyada ve ülkemizde en çok kullanılan yapı malzemesi olan beton agrega, su, çimento ve gereken durumlarda mineral ya da kimyasal esaslı katkı malzemelerinin kullanılmasıyla hazırlanan taneli kompozit bir malzemedir. Üretiminin basit oluşu kalıp sistemi sayesinde istenilen şekle sokulabilmesi ön döküm veya yerinde döküm şeklinde kullanıma sunulması betonu çok cazip bir yapı malzemesi haline getirmektedir. Günümüzde betonun kullanılmadığı alan neredeyse yoktur. Tarihi yap1 restorasyonu, temel ve zemin uygulamaları, tünel, köprü, karayolu ve betonarme konutlar betonun kullanım alanlarından bazılarıdır[1]. Beton endüstrisi ise bu talepler karşısında sürekli kendini geliştirme çabasındadır [2]. Beton malzemesinin ana bileşenlerinden olan çimento günümüz ihtiyaçlarını karşılamakta, ancak üretim tekniği sebebiyle çevreye verdiği zararlardan ötürü beton üreticilerinin alternatif malzeme arayışlarını sürekli canlı tutmuştur. Mineral esaslı beton katkıları elde ediliş yöntemlerine göre doğal ve yapay olarak iki gruba ayrılırlar. Bu malzemeler genellikle amorf yapılı malzemeler olup çok ince öğütüldüklerinde çimento hidratasyonu sonucu ortaya çıkan $\mathrm{Ca}(\mathrm{OH})_{2}$ ile tepkimeye girerek aktive olurlar. Doğal puzolanlar; volkanik, sedimenter ve diyajenetik olarak 3 ana başlıkta ayrılırlar. Volkanik puzolanlar yine kendi arasında küller, tüfler ve camlar olarak üç gruba ayrılır. Doğal puzolanlar yalnız başlarına bağlayıcı olmamalarına rağmen çimento gibi bağlayıcı bir malzeme ile beraber mineral katkı olarak kullanıldıklarında harç ve betonun kimyasal ve fiziksel özelliklerini olumlu yönde geliştiren malzemelerdir [3]. Sedimanter kökenliler ise volkanizmanın devam ettiği süreç içinde, volkanik küllerin sediman malzeme ile karışması ile oluşan malzemeler olup tüfit olarak isimlendirilir. Bu malzemelerin araştırmalarda volkanik tüflerle karıştırılmaması gerekir. Volkanitlerin beton teknolojisinde kullanımıyla ilgili yapılan çalışmada Türkiye'de bol miktarda bulunan volkanitlerin ülke sermayesine katılarak hem yeni iş alanları oluşturulması hem de ekonomik kalkınmaya katkı sağlaması amaçlanmıştır.

\section{AFYON VE KÜTAHYA YÖRESI VOLKANITLERI}

Geçmişteki plaka hareketlerinin belirlenmesinde rol alan volkanik oluşumlar üzerinde son zamanlarda birçok araştırmacı tarafından mineralojik, petrografik, jeokimyasal ve jeokronolojik çalışmalar yapılmıştır. Afyon yöresinde 1982'den beri yapılan araştırmalar neticesinde bol miktarda volkanit (özellikle tüf, pomza parçaları içeren tüf, ignembirit “lehimlenmiş tüf - welded tuff') ve Terra Rosa rezervi olduğu saptanmıştır [4]. Volkanik kayaçların (Andezit, trakit, trakiandezit, riyolit, dasit, riyodasit, bazalt vb.) ve özellikle volkanik tüflerin doğal yapı taşı olarak kullanılabilme ve kolay kazılabilme özelliğine sahip olması nedeniyle puzolan katkılı çimento üretiminde kullanılması önerilmiştir. Afyon ve Kütahya bölgesi Türkiye'nin Ege bölgesinde bulunan illeridir. Afyon İli $14.295 \mathrm{~km}^{2}$ yüz ölçümüne sahip olup Türkiye'nin termal başkenti olarak bilinmektedir. Afyon Ege bölgesinde bulunsa da iklim olarak İç Anadolu bölgesi iklimine daha yakındır. Kışları soğuk ve kar yağışlı yazları sıcak ve kurak step iklimi görülür. Kütahya ise $12.043 \mathrm{~km}^{2}$ yüz ölçümüne sahip olup Ege bölgesindeki ilimizdir. İlin temel geçim kaynaklarını seramik fabrikaları ve termal tatil köyleri oluşturmaktadır. Her iki ilimizin ortak özelliği olan termal tesisler illerimizin volkanik geçmişiyle ilgilide bilgi vermektedir. Çalışma alanı haritaları Şekil 1 'de görülmektedir.

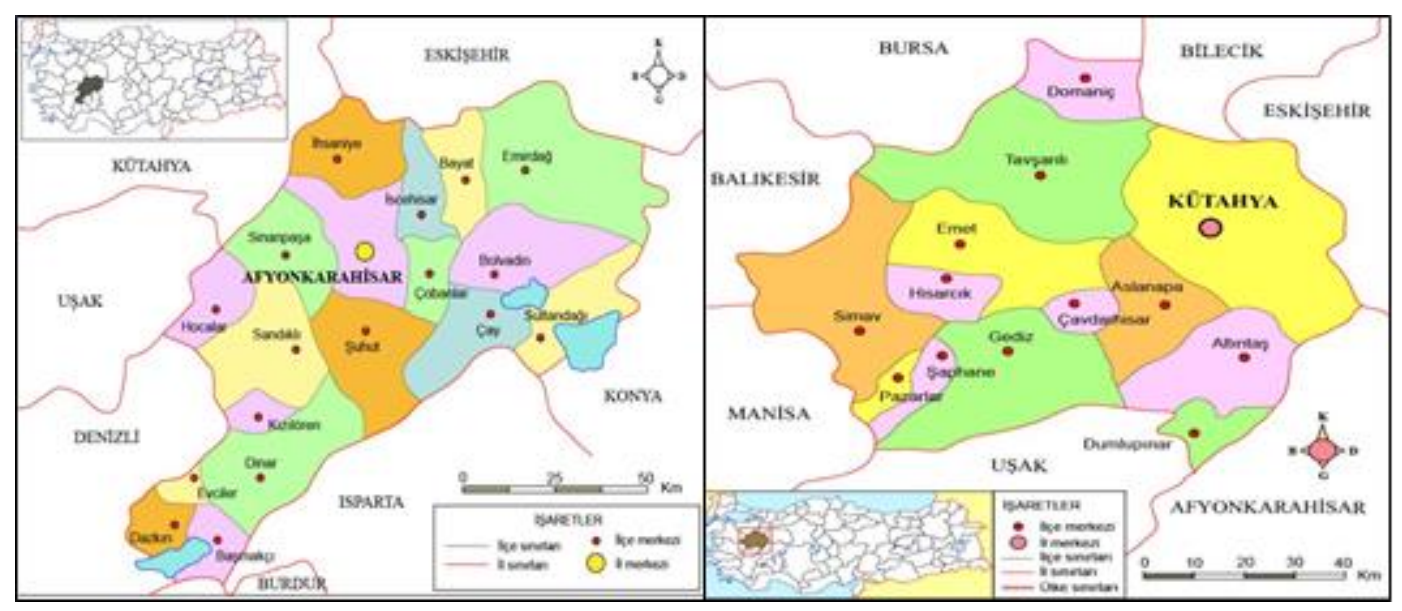

Şekil 1. Afyon ve Kütahya bölgesi haritaları 
Çalışmada kullanılan volkanik tüfler değişik aşamalarda ve zaman dilimlerinde gelişmiş olan volkanizma faaliyetleri sonucunda oluşan hafif gözenekli özellikler gösteren bir kayaç türüdür. Özellikle Afyon yöresi ve yakın çevresinde yine volkanizma faaliyetleri sonucu volkanizmanın patlama sürecinde gölsel ortamda çökelen sedimanter kayaçlarla ardaşıklı olarak oluşum sergileyen volkanik küller yer almaktadır. Bu oluşumlar aktif veya sönmüş volkanların yamaçlarında tabakalaşmış şekilde bulunur [4, 5]. Volkanik tüflerin gözenekli halde oluş sebebi yüzeye çıkan lavların soğuma esnasında oluşan volkanik malzemenin içerisinde bulunan gazların hapsolarak katı kütle içerinde dağılmasıdır [4, 6]. Pomza ise, riyolit bileşim ve içerisinde \%2-5 oranında su (magma kökenli jüvenil su) içeren asidik bir kayaç olup, bol miktarda mm-mikron mertebesinde birbirinden bağımsız küresel boşluklar içeren gözenekli ve hafif yapısıyla karakterize edilir. Pomza kimyasal olarak amorf alüminyum silikat olarak tanımlanır [4,7]. Dünyada Amerika'dan sonra en fazla pomza rezervi olan ülke Türkiye'dir. Doğal olarak bulunan pomzanın ocaklardan açık işletmelerden çıkarılması ise mekanik kazı yoluyla yapılmaktadır. Terra rosa ise sert kristalin kireçtaşı ve dolomitik kireçtaşlarının ayrışması sonucu oluşur. Doğal oluşum ürünü olan bu malzemeler Türkiye'nin Akdeniz (Isparta), Batı (Kütahya-Afyon), İç Anadolu (Nevşehir), Doğu ve Güney kesimlerinde bolca bulunur. Bu topraklar kil bakımından zengindir [8]. Afyon ve Kütahya yöresinde 1982'den beri yapılan araştırmalarda bol miktarda volkanit rezervi olduğu saptanmıştır $[4,8,9]$.

Afyon ve Kütahya illerinin çevresinde var olan volkanitler ile ilgili çeşitli araştırmacılar çeşitli çalışmalar yapmışlardır. Beycioğlu (2005) Pomza agregalı betonlara silis dumanı ekleyerek yaptığı araştırmada işlenebilirliğin düştüğünü saptamıştır [10]. Yazıcıoğlu (2013) pomza katkılı hafif betonun mekanik özelliklerini araştırmıştır. Araştırma sonucu pomzanın taşıyıcı hafif beton üretiminde kullanılabileceği görülmüş̧ür [11]. Gökçe (2013) çimento yerine belli oranlarda tüf katkılı betonların alkali silika reaksiyonu etkilerini araştırmıştır. Araştırma sonucu 14 ve 28 günlük numunelerin genleşme sınırını aştı̆̆ını saptamıştır [12]. Korkmaz (2019) Yozgat yöresindeki tüflerin çimento üretiminde kullanımıyla ilgili araştırmalar yapmıs ve $\% 40$ orana kadar tüf kullanımının çimento üzerinde erken ve geç dayanımların arttığını tespit etmiştir [13]. Akyüncü (2019) yine pomza madenini betonda agrega olarak kullanarak mekanik davranışlarını incelemiş̧ir. Yapılan çalışmada pomza kullanılan betonlarda birim ağırlı̆ıı \%40'a kadar düştüğünü, pomza kullanımının \%30-70 arasında arttığında, dayanımların \%35-45 arasında azaldığını belirlemiştir [14]. Yapılan bir diğer çalışmada ise volkanik kökenli doğal puzolanların betonda katkı malzemesi olarak kullanılması ile betonda su emme, dayanım ve donma-çözülme davranışları üzerinde olumlu etkilerinin olduğu ifade edilmiştir [15].

\section{MALZEME VE YÖNTEM}

\section{A. Malzeme}

Çalışmada agrega olarak Bilecik Dağ-İs Madencilik ocağından temin edilen üç farklı tane boyutuna sahip (0-4 mm, 4-11,2 mm ve 11,2-22,4 mm) kalker kökenli kırmataş agregaları kullanılmıştır. Çimento olarak Eskişehir Çimsa çimento fabrikası üretimi olan CEM I 42,5 R tipi Portland çimentosu kullanılmıştır. Mineral katkı olarak kullanılacak volkanitlerden tüf Afyon-Gecek kaplıcaları bölgesinden, terra rosa Kütahya-Çögürler köyü ve pomza Kütahya Kumluyurt ve Göçeri köyleri arasındaki alandan saha çalışmalarıyla elde edilmiştir. Sahadan elde edilen malzemeler Şekil 2'de görülmektedir.

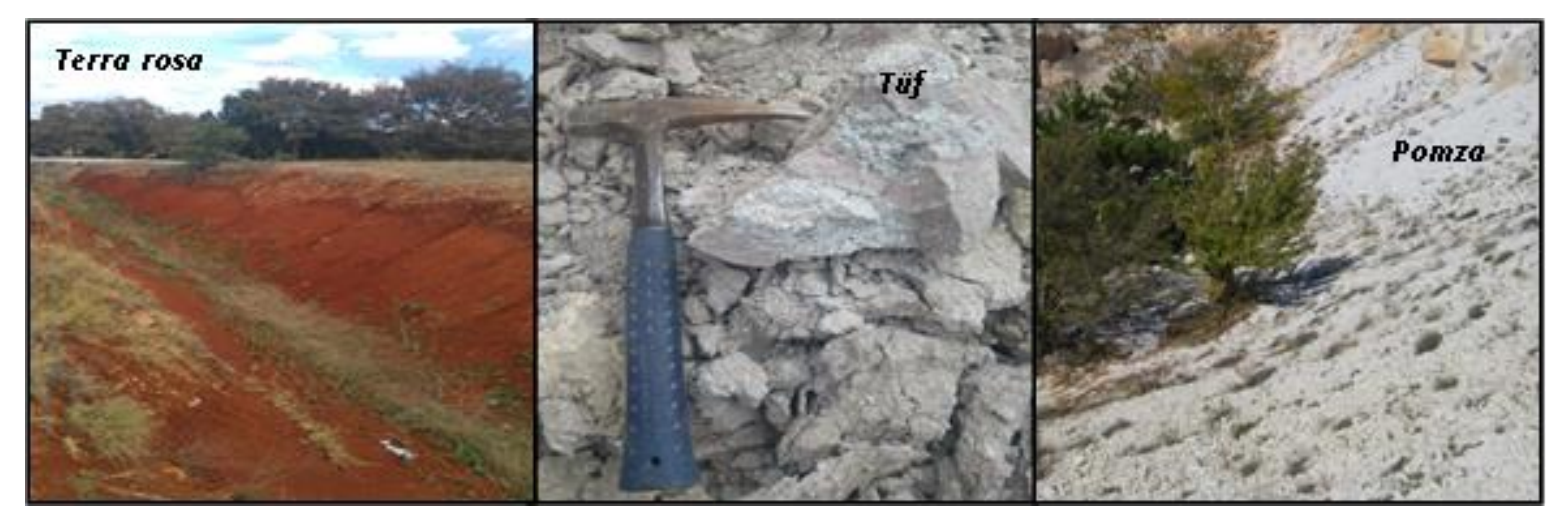

Şekil 2. Volkanitlerin araştırma bölgesindeki temin alanları 
Beton karışım suyu olarak Bilecik şehir şebeke suyu kullanılmıştır. Beton işlenebilirliğini düzenlemek için ise Polisan kimya üretimi olan sülfonat esaslı Süperton $278 \mathrm{~S}$ model kimyasal katkı kullanılmıştır. Kullanılan akışkanlaştırıcı katkı oranı sabit tutularak mineral katkı kullanımındaki değişimin beton işlenebilirliği üzerindeki etkileri belirlenmeye çalışılmıştır. Beton üretiminde kullanılan malzemelerin bazı fiziksel özellikleri Tablo 1'de verilmiştir.

Tablo 1. Malzemelerin fiziksel özelikleri

\begin{tabular}{lcc}
\hline Malzeme & Özgül ağırlık & $\begin{array}{c}\text { İncelik } \\
\mathbf{c m}^{2} / \mathbf{g r}\end{array}$ \\
\hline Çimento & 3.06 & 3641 \\
Terra Rosa & 2.65 & 3354 \\
Tüf & 2.76 & 4854 \\
Pomza & 2.50 & 3891 \\
Kırmataş agrega & 2.63 & - \\
\hline
\end{tabular}

\section{B. Yöntem}

Hammaddelerin bulunduğu alanları gösteren jeolojik haritalardan bölge tespiti yapıldıktan sonra sahada inceleme yapılarak hammaddeler yerinden küçük kayaçlar halinde toplanarak Bilecik Şeyh Edebali Üniversitesi Yapı Malzemeleri Laboratuvarına getirilerek burada bulunan çeneli kırıcı ve bilyalı değirmen yardımıyla ögütülerek karışımlarda kullanılmıştır. Pomza ve tüf ilk olarak çeneli kırıcılarda $4 \mathrm{~mm}$ çaplı dane boyutuna indirgenmiş ardından bilyalı değirmen ile çimento inceliğinde öğütülmüşsür. Ardından öğütülen malzemeler 90 $\mu \mathrm{m}$ 'lik elekten elendikten sonra kullanılmıştır. Terra rosa doğrudan beton karışımlarında kullanılmamış olup kil ve kireçtaşı kökenli olması nedeniyle kalsine olması amacıyla ilk olarak kül firınında $40 \mathrm{dk}$ süre ile $950^{\circ} \mathrm{C}$ sıcaklıkta bekletilmiştir. Fırından alınan kalsine edilmiş malzeme üzerine hava üfleciyle soğuk hava üflenerek amorf yapı eldesi amacıyla ani soğuma etkisi sağlanmıştır. Çıkan ürün ardından bilyalı değirmende çimento inceliğinde öğütülmüştür (Şekil 3).

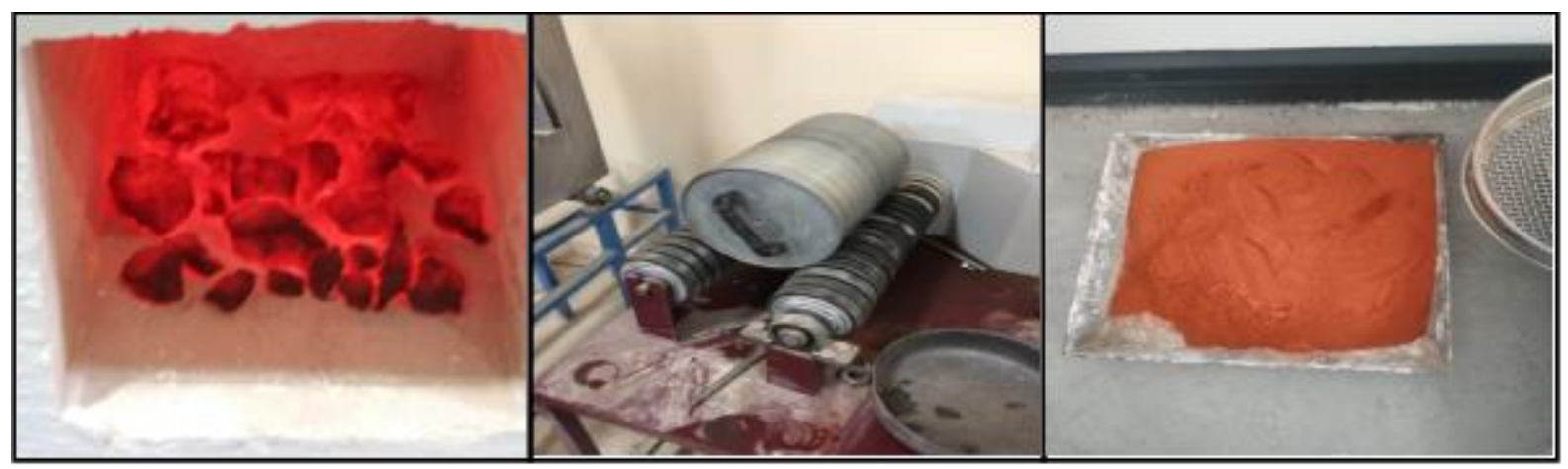

Şekil 3. Terra rosa malzemesinin kalsinasyon ve öğütme süreçleri

Beton karışımında kullanılacak agregaların elek analizleri yapılarak karışım agrega granülometrisi belirlenerek Şekil 4'te sunulmuştur. İdeal agrega granülometrisinde TS 802 standardına uygun olarak beton karışım hesabı yapılmış olup [16] $1 \mathrm{~m}^{3}$ beton için karışım oranları Tablo 2'de sunulmuştur. Karışım oranlarına göre hazırlanan kuru karışım düşey eksenli laboratuvar tipi karıştırıcıda önce kuru sonra su ile katkının karışımı ile karıştırılarak homojen taze beton karışımları elde edilmiştir.

Üretilen betona ilk olarak taze beton deneylerinden olan çökme ve yayılma tablası deneyleri yapılmıştır. Çökme deneyi TS EN 12350-2'ye göre yapılmıştır. Deney yapılacak numune $30 \mathrm{~cm}$ yükseklikli yarım koni kalıba 3 kademede yerleştirilmiştir. Her kademede $16 \mathrm{~mm}$ çaplı beton şişleme çubuğu ile 25 şişleme yapılmıştır. Ardından yarım koni kalıp çekilerek betondaki çökme değerleri not edilmiştir [17]. 


\begin{tabular}{|c|c|c|}
\hline & $\begin{array}{l}\text { BŞEÜ Fen Bilimleri Dergisi } \\
8(1), 100-108,2021\end{array}$ & $\begin{array}{r}\text { BSEU Journal of Science } \\
\text { https://doi.org/10.35193/bseufbd.843402 }\end{array}$ \\
\hline & & 2458-7575 (https://dergipark.org.tr/tr/pub/bseufbd) \\
\hline
\end{tabular}

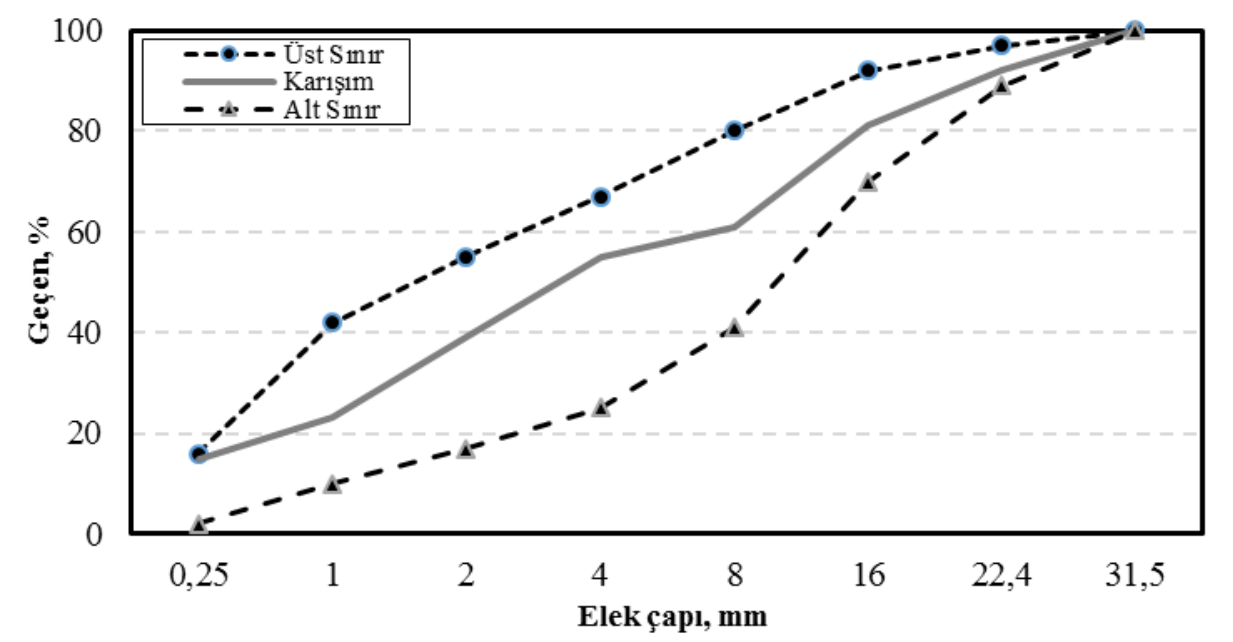

Şekil 4. Beton agregalarının karışım granülometrisi

Tablo 2. Beton karışım oranları $\left(1 \mathrm{~m}^{3}\right)$

\begin{tabular}{|c|c|c|c|c|c|c|c|c|c|}
\hline Karışım & $\begin{array}{c}\text { Çimento } \\
\text { kg }\end{array}$ & $\begin{array}{l}\text { Su } \\
\text { kg }\end{array}$ & $\begin{array}{c}0-4 \mathrm{~mm} \\
\mathrm{~kg}\end{array}$ & $\begin{array}{c}4-11.2 \mathrm{~mm} \\
\mathrm{~kg}\end{array}$ & $\begin{array}{c}11.2-22.4 \mathrm{~mm} \\
\mathrm{~kg}\end{array}$ & $\begin{array}{c}\text { K. katkı } \\
\text { kg }\end{array}$ & $\begin{array}{l}\text { Tüf } \\
\text { kg }\end{array}$ & $\begin{array}{c}\text { Pomza } \\
\text { kg }\end{array}$ & $\begin{array}{c}\text { T. rosa } \\
\text { kg }\end{array}$ \\
\hline Referans & 330 & 170 & 1000 & 250 & 560 & 4.5 & - & - & - \\
\hline TÜF10 & 297 & 170 & 1000 & 250 & 560 & 4.5 & 33 & - & - \\
\hline TÜF 20 & 264 & 170 & 1000 & 250 & 560 & 4.5 & 66 & - & - \\
\hline TÜF 30 & 231 & 170 & 1000 & 250 & 560 & 4.5 & 99 & - & - \\
\hline PMZ 10 & 297 & 170 & 1000 & 250 & 560 & 4.5 & - & 33 & - \\
\hline PMZ 20 & 264 & 170 & 1000 & 250 & 560 & 4.5 & - & 66 & - \\
\hline PMZ 30 & 231 & 170 & 1000 & 250 & 560 & 4.5 & - & 99 & - \\
\hline TRS 10 & 297 & 170 & 1000 & 250 & 560 & 4.5 & - & - & 33 \\
\hline TRS 20 & 264 & 170 & 1000 & 250 & 560 & 4.5 & - & - & 66 \\
\hline TRS 30 & 231 & 170 & 1000 & 250 & 560 & 4.5 & - & - & 99 \\
\hline
\end{tabular}

Yayılma tablası deneyi TS EN 12350-5'e göre yapılmıştır. Taze beton standart yarım koni kalıba iki kademede kare kesitli özel tokmak ile yerleştirilmiştir. Ardından yarım koni kalıp çıkarılarak beton numunesine pimli levha üzerinde $15 \mathrm{kez} 4 \mathrm{~cm}$ 'lik düşü yapılarak deney sonunda yatay ve düşey doğrultuda ölçülen yayılma çaplarının ortalaması alınarak beton yayılma çapı sonuçları belirlenmiştir [18]. Taze beton deneylerinin gerçekleştirilmesiyle ilgili görseller Şekil 5 'te verilmiştir.

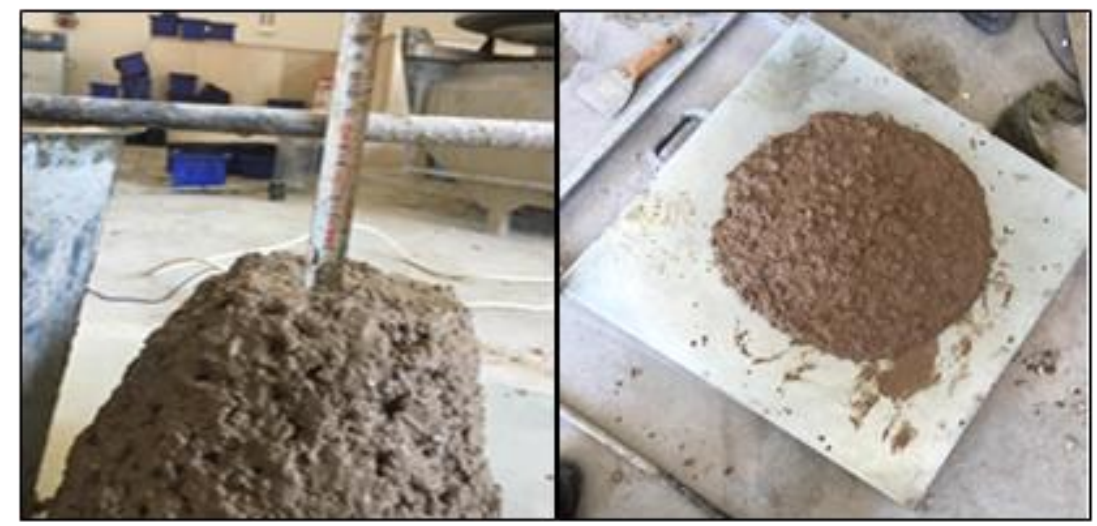

Şekil 5. Taze betonda çökme ve yayılma tablası deneyinin yapılışı

Taze beton deneyleri yapıldıktan sonra sertleşmiş beton deneylerinin yapılacağı numuneler $150 \mathrm{~mm}$ kesitli küp kalıplara yerleştirilerek laboratuvar koşullarında 24 saat süreyle kalıpta bekletilmiştir. Kalıptan çıkarılan sertleşmiş beton numuneleri $20 \pm 2^{\circ} \mathrm{C}$ sıcaklıktaki kirece doygun kür havuzunda 2, 7, 28 ve 90 günlük 


\begin{tabular}{|c|c|c|}
\hline & $\begin{array}{l}\text { BŞEÜ Fen Bilimleri Dergisi } \\
8(1), 100-108,2021\end{array}$ & $\begin{array}{r}\text { BSEU Journal of Science } \\
\text { https://doi.org/10.35193/bseufbd.843402 }\end{array}$ \\
\hline $\begin{array}{l}\text { KSEYHED } \\
\text { ERSIT }\end{array}$ & & 2458-7575 (https://dergipark.org.tr/tr/pub/bseufbd) \\
\hline
\end{tabular}

numune yaşlarına ulaşana kadar bekletilmiştir. Kür süresi tamamlanan numuneler havuzdan çıkartıldıktan sonra yüzeyleri kurulanıp birim hacim ağırlıkları belirlenmiştir. Sonrasında beton numunelerinin basınç dayanımları tek eksenli Çevik Makine markalı 200 ton kapasiteli basınç presinde ölçülmüştür.

\section{DENEYSEL ÇALIŞMA SONUÇLARI}

\section{A. İşlenebilirlik Deney Sonuçlart}

Karışım oranlarına uygun olarak hazırlanan beton karışımlarının işlenebilirlikleri çökme ve yayılma tablası deneyleri ile belirlenmiştir. Elde edilen deney sonuçları Tablo 3 'te verilmiştir. İlgili sonuçlar incelendiğinde genel davranış olarak tüf ve pomza katkılı betonlarda işlenebilirliklerin hem çökme hem de yayılma tablası değerlerinde katkı kullanım oranındaki artışa bağlı olarak azaldıkları görülmüştür. Özellikle tüfün ince gözenekli yapısı nedeniyle beton kıvamında ciddi azalmalar gözlenmiştir. Bu nedenle \%20 üzerindeki oranlarda tüf kullanımında akışkanlaştırıcı katkı miktarının beton karışımında artırılması gerektiği düşünülmektedir. Kalsine edilmiş terra rosa ise beton işlenebilirliğinde olumsuz bir etkiye neden olmamıştır. Hatta bunun ötesinde TRS 30 karışımında beton işlenebilirliğinin \%30 oranında iyileştiği görülmüştür. Bu etkinin altında ise kalsine terra rosa katkısının akışkanlaştırıcı katkı ile uyumlu çalışması ve taze betonun iç sürtünmesini azaltıcı yönde filler etkisinin rol oynadığı düşünülmektedir. Terra rosa kullanılan betonlarda yüksek işlenebilirlik oranı olduğundan, kendiliğinden yerleşen beton teknolojisinde toz malzeme olarak değerlendirilebileceği saptanmıştır [2,19].

Tablo 3. Taze betonda çökme ve yayılma tablası deney sonuçları

\begin{tabular}{ccc}
\hline Karışım & $\begin{array}{c}\text { Çökme } \\
\text { cm }\end{array}$ & $\begin{array}{c}\text { Yayılma } \\
\text { mm }\end{array}$ \\
\hline Referans & 10 & 370 \\
TÜF10 & 4 & 220 \\
TÜF 20 & 3 & 210 \\
TÜF 30 & 1 & 190 \\
PMZ 10 & 6 & 360 \\
PMZ 20 & 8 & 370 \\
PMZ 30 & 8 & 340 \\
TRS 10 & 10 & 370 \\
TRS 20 & 10 & 400 \\
TRS 30 & 13 & 460 \\
\hline
\end{tabular}

\section{B. Birim Ă̆ırlık Deney Sonuçlart}

Sertleşmiş beton numunelerinin beton basınç dayanımı deneyi öncesinde 2, 7, 28 ve 90 gün sonundaki suya doygun halde sertleşmiş beton birim ağırlıkları Tablo 4 'te görülmektedir. Elde edilen sonuçlardan volkanik tüf katkılı beton numunelerinin her yaş için katkı oranındaki artışa bağlı olarak birim ağırlık değerlerinde azalma yönünde davranış gösterdiği tespit edilmiştir. Bu kütle kaybı 90 günlük tüf numunelerinde \% 4.5 seviyelerine kadar ulaştı̆̆ı görülmüştür. Volkanit katkılı beton karışımlarının birim ağırlıklarının azalmasında hem gözeneklilik hem de bu katkı malzemelerinin özgül ağırlıklarının çimentoya oranla daha düşük olması rol oynamıştır.

Tablo 4. Sertleşmiş beton numunelerine ait birim hacim ağırlık değerleri

\begin{tabular}{|c|c|c|c|c|}
\hline Karışım & $\begin{array}{c}\text { Birim Ă̆ırlık } \\
2 \text { gün } \\
\text { kg/m } / \mathbf{m}^{3} \\
\end{array}$ & $\begin{array}{c}\text { Birim Ăğırlık } \\
7 \text { gün } \\
\text { kg/m } / \mathrm{m}^{3} \\
\end{array}$ & $\begin{array}{c}\text { Birim Ă̆ı̆ırık } \\
28 \text { gün } \\
\text { kg/m } / \mathbf{m}^{3} \\
\end{array}$ & $\begin{array}{c}\text { Birim Ağırlık } \\
90 \text { gün } \\
\text { kg/m } \\
\end{array}$ \\
\hline Referans & 2400 & 2414 & 2408 & 2417 \\
\hline TÜF10 & 2354 & 2347 & 2331 & 2324 \\
\hline TÜF 20 & 2373 & 2377 & 2369 & 2331 \\
\hline TÜF 30 & 2370 & 2391 & 2365 & 2311 \\
\hline PMZ 10 & 2400 & 2387 & 2363 & 2373 \\
\hline PMZ 20 & 2379 & 2378 & 2374 & 2398 \\
\hline PMZ 30 & 2370 & 2381 & 2406 & 2416 \\
\hline TRS 10 & 2409 & 2399 & 2437 & 2449 \\
\hline TRS 20 & 2360 & 2377 & 2406 & 2342 \\
\hline TRS 30 & 2391 & 2384 & 2362 & 2349 \\
\hline
\end{tabular}




\begin{tabular}{|c|c|c|}
\hline & $\begin{array}{l}\text { BŞEÜ Fen Bilimleri Dergisi } \\
8(1), 100-108,2021\end{array}$ & $\begin{array}{r}\text { BSEU Journal of Science } \\
\text { https://doi.org/10.35193/bseufbd.843402 }\end{array}$ \\
\hline & & 2458-7575 (https://dergipark.org.tr/tr/pub/bseufbd) \\
\hline
\end{tabular}

\section{Basınç Dayanımı Deney Sonuçları}

Kür havuzunda deney gününe kadar standart koşullarda şartlandırılan beton numuneleri eksenel basınç deneyine tabi tutulmuş olup elde edilen sonuçlar Şekil 6'da sunulmuştur. Erken yaş dayanım performansı incelendiğinde tüm katkı türlerinde basınç dayanımlarının referans numunesine göre $\% 3.5$ ile $\% 60$ arasında azaldıkları gözlemlenmiştir. Buradaki en yüksek dayanım kaybı tüf katkılı TÜF 30 numunesinde görülmüşsür. İlk bir haftalık beton yaşı sonunda tüf katkılı numunelerin tümünde basınç dayanımları referans numunesinin altında kalırken pomza ve kalsine terra rosa katkılı numunelerde $\% 10$ ve $\% 20$ katkı oranlarında referans numunesinden daha yüksek dayanım değerleri elde edilmiştir. Özellikle TRS 10 numunesinde referans numunesine göre \% 14 oranında daha yüksek basınç dayanımı elde edilmiştir. Benzer davranış 28 günlük numunelerde de gözlenmiş olup bu yaşta en düşük dayanım performansını tüf katkılı numuneler göstermiştir. İleri yaş dayanım performansı açısından referans numunesine göre \% 10 katkılı PMZ 10 ve TRS 10 numuneleri referans numunesiyle neredeyse aynı dayanım değerini vermiştir. Pomza ve terra rosa katkılı betonlarda \% 30 oranına kadar katkı kullanımının ekonomik beton üretimine katkı vereceği düşünülmektedir.

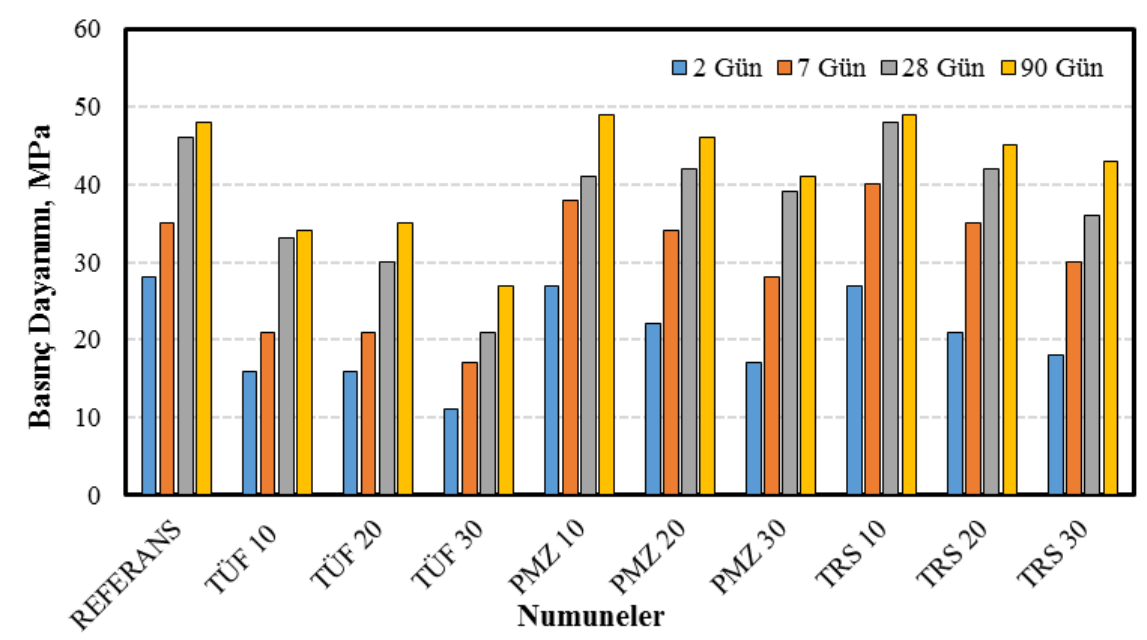

Şekil 6. Kür sürelerine göre beton basınç dayanımları karşılaştırması

Yukarıda ki veriler incelendiğinde referans numuneye oranla volkanit kullanılan betonlarda çok farklı basınç kayıpları oluşmamış olup olumlu konuşmak mümkündür. Özellikle terra rosa kullanılan betonlarda basınç dayanımlarının referans numuneden daha iyi sonuç verdiği açıkça gözükmektedir. Pomza kullanılan betonların referans betona göre geç dayanım kazandığını söylemek mümkündür ancak ileri priz sürelerinde yüksek dayanımı yakaladığı gözlenmiştir. Çimento yerine kullanılacak olan bu volkanitlerin beton üretiminde kullanımıyla çimento tüketiminin azalması, bölge ekonomisine katkı, zaman ve işçilikten kazanç gibi kazanımların elde edilebileceği düşünülmektedir [20]. Pomza ve tüf katkılı betonların yapı kütlesinde azalmaya neden olmasının deprem kaynaklı zorlamaların etkilerinin azaltılabilmesine katkı sağlayacağı öngörülmüştür [21,22].

\section{SONUÇ VE ÖNERILLER}

Deneysel çalışmalar kapsamında elde edilen sonuçlardan elde edilen sonuç ve öneriler sırasıyla aşağıda sunulmuştur. Buna göre;

- Çökme deneyi sonuçlarından tüf katılan beton karışımlarının su emme oranının çok yüksek olduğu, bu nedenle kıvam kayıplarına yol açarak işlenebilirliğin \%90’lara kadar azalmasına yol açtığı gözlemlenmiştir. Terra rosa kullanıldığında ise taze beton işlenebilirliğinin \%60’a kadar arttığı saptanmıştır.

- Sarsma tablası deneyinden elde ettiğimiz sonuçlara göre terra rosa kullanım oranı arttıkça betonun akışkanlığının arttığı dolayısıyla işlenebilirliğin arttığını söylemek mümkündür. Pomza kullanılan betonlarda İşlenebilirliğin referans numuneye göre \%15 azaldığı saptanmıştır.

- Birim hacim ağırlık deneyi sonuçlarına göre pomza kullanılan betonlarda betonda $\% 2$ kadar hafifleme gözlemlenmiştir. Tüf kullanılan betonlarda bu hafifleme \%4'e kadar ulaşmıştır. 
- Basınç dayanımları incelendiğinde, tüf katılan betonlarda referans numuneye oranla basınç dayanımlarının \%40 düştüğü gözlemlenmiştir. Pomza kullanılan betonlarda erken yaşlarda dayanımların referans numuneyi yakalayamadığı ancak ileri yaş dayanımlarının puzolanik aktivite sonucu referans numuneye yakın çıktığı saptanmıştır. Terra rosa kullanılan betonlarda erken yaş dayanımlarının referans numuneye oranlar daha çabuk dayanım kazandığı gözlemlenmiştir. Basınç dayanımında olan değişim numunelerin sertleşmiş birim ağırlık değerleri ile orantılı olarak değişim gösterdiği görülmüştür.

- Kullanılan malzemelerin puzolanik aktivite sonucu referans numune dayanımlarının yakalandığı çimento yerine kullanılabileceği saptanmıştır. Dolayısıyla volkanitlerin kullanımının hem malzeme hem de işçilik maliyetleri yönünden kazanç sağlayacağı belirlenmiştir. Ayrıca doğal kaynakların kullanımı ile kalıcı ve sürdürülebilir bir beton üretiminin mümkün olacağı düşünülmektedir.

- Yapılan çalışmada kullanılan doğal malzemelerin beton teknolojisinde kullanılabileceği elde edilen olumlu sonuçlardan görülmektedir. Bu sebeple bu madenlerin işlenip öğütülerek ülke ekonomisine kazandırılması önerilmektedir.

\section{TEŞEKKÜR}

Yapılan bu çalışma 2018-02.BŞEÜ.03-04 numaralı proje kapsamında yapılmış olup yazarlar desteğinden ötürü Bilecik Şeyh Edebali Üniversitesi Bilimsel Araştırma Projeleri Koordinatörlüğüne teşekkür eder.

\section{KAYNAKLAR}

[1] Kap, T, Sağlık, M. (2018). Tarihi eser restorasyonunda beton teknolojisi kullanımı. Ileri Teknoloji Bilimleri Dergisi, 7 (2), 88-99.

[2] İnce, H., Öcal, C., Alkan Çakıroğlu, M., Çelik, S. (2015). Püskürtme Beton Uygulamaları ve Kullanım Alanlar1. Mehmet Akif Ersoy Üniversitesi Fen Bilimleri Enstitüsü Dergisi, 6 (2), 100-107.

[3] Kırgız, M. (2016). Mineralojik katkıların çeşitli tanımları, sınıfları, özellikleri ve kullanım alanları (Bölüm 1). Trakya Üniversitesi Fen Bilimleri Dergisi, 9 (2), 118-127.

[4] Kibici, Y., Dinç, D., Uçar, A. (2012). Afyonkarahisar Yöresi Volkanik Kayaçlarının Mineralojik ve Petrografik Özellikleri. Journal of Science and Technology of Dumlupınar University, (029), 53-70.

[5] Çelik, M., Kavas, T. (2001). Elvanpaşa (Afyon) Trakiandezitlerinin Jeolojisi Ve Yapı Taşı Olarak Kullanılabilirliğinin Araştırılması. Eskişehir Osmangazi Üniversitesi Mühendislik ve Mimarlık Fakültesi Dergisi, 14 (2), 24-36.

[6] Bayırl1, M., Pekin, A. (2013). Volkanik Tüf Yüzeyi Gözeneklerinin Özeliklerinin Birikinti Geometrisi Kullanarak İncelenmesi. Balıkesir Üniversitesi Fen Bilimleri Enstitüsü Dergisi, 15 (2), 66-72.

[7] Kılınç Aksay, E., Akar, A., Cöcen, İ. (2016). Pomza Cevherinin Hazırlanması ve Zenginleştirilmesi. Afyon Kocatepe Üniversitesi Fen Ve Mühendislik Bilimleri Dergisi, 16 (2), 384-390.

[8] Karadağ, M., Arık, F., Öztürk, A. (2006). Çatmakaya (Seydişehir-Turkiye) boksit yatağının kökenine jeoistatistiksel ve jeokimyasal bir yaklaşım. Yerbilimleri, 27 (2), 63-85.

[9] Doğan Külahc1, G., Temel, A., Gourgaud, A., Demirbağ, H. (2016). Afyon Volkanik Kayaçlarının (Batı Anadolu, Türkiye) Mineralojik-Petrografik Özellikleri ve P-T Hesaplamaları. Yerbilimleri, 36 (3), 137-162.

[10] Beycioğlu, A., Başyiğit, C., Kılınçarslan, Ş. (2014). Pomza Agregalı Hafif Beton Özelliklerine Silis Dumanının Etkisi. Süleyman Demirel Üniversitesi Fen Bilimleri Enstitüsü Dergisi, 14 (2), 200-205.

[11] Yazıcıŏlu, S., Bozkurt, N. (2013). Pomza ve mineral katkılı taşıyıcı hafifbetonun mekanik özelliklerinin araştırılması. Gazi Üniversitesi Mühendislik Mimarlık Fakültesi Dergisi, 21 (4), 675-680.

[12] Gökçe, H., Taban, S., Şimşek, O. (2013). Zeolitik tüf ikamesinin farklı agregalar üzerinde alkali-silika reaksiyonu etkilerinin belirlenmesi. Gazi Üniversitesi Mühendislik Mimarlık Fakültesi Dergisi, 25 (4), 803 809.

[13] Korkmaz, A. (2019). Yozgat Yöresi Tüflerinin Çimento Katkısı Olarak Kullanılabilirliğinin İncelenmesi. Yerbilimleri, 40 (3), 253-267.

[14] Akyüncü, V. (2019). Pomza agregalı hafif beton blokların mekanik özelliklerinin ve yangın etkisi altındaki davranışının incelenmesi. Niğde Ömer Halisdemir Üniversitesi Mühendislik Bilimleri Dergisi, 8 (1) , 147 157.

[15] Nagrockienè, D., Girkas, G., \& Skripkūnas, G. (2017). Properties of concrete modified with mineral additives. Construction and Building Materials, 135, 37-42.

[16] TS 802. (2016). Beton karışım tasarımı hesap esasları. Türk Standartları Enstitüsü, Ankara. 
[17] TS EN 12350-2. (2019). Beton - Taze beton deneyleri - Bölüm 2: Çökme (slump) deneyi. Türk Standartları Enstitüsü, Ankara.

[18] TS EN 12350-5. (2019). Beton - Taze beton deneyleri - Bölüm 5: Yayılma tablasl deneyi, Türk Standartları Enstitüsü, Ankara.

[19] Topçu, İ., Bilir, T., Baylavlı, H. (2008). Kendiliğinden Yerleşen Betonun Özellikleri, Eskişehir Osmangazi Üniversitesi Mühendislik ve Mimarlık Fakültesi Dergisi, 21 (1), 1-22.

[20] Şahin, R., Taşdemir, M., Gül, R., Çelik, C. (2011). Taze Beton Özelliklerinin Optimizasyonu . Atatürk Üniversitesi Ziraat Fakültesi Dergisi , 38 (2), 127-135.

[21] Kavas, T., Çelik, M. (2001). Ayazını (Afyon) tüflerinin çimento sanayiinde tras olarak kullanılabilirliğinin incelenmesi. Bilimsel Madencilik Dergisi, 40 (4), 39-46.

[22] Uzun, M., Korkmaz, H0. (2019). Deprem bölgesindeki bazı ülkelerde eşdeğer deprem yükü metodunun karşılaştırılması. Selçuk Üniversitesi Mühendislik, Bilim ve Teknoloji Dergisi, 7 (1), 189-212. 